\title{
Construction of rational regimes in motor activity of children aged 3-4 years in pre-school educational institutions of various types
}

\author{
Moskalenko N.V. ${ }^{\mathrm{ABCDE}}$, Poliakova A.V. ${ }^{\mathrm{ABCDE}}$, Sidorchuk T.V. ${ }^{\mathrm{ADE}}$ \\ Pridneprovsk State Academy of Physical Culture and Sports, Ukraine
}

Authors' Contribution:

A - Study design; B - Data collection; C - Statistical analysis; D - Manuscript Preparation; E - Funds Collection.

\begin{abstract}
Purpose: $\quad$ to develop rational regimes of physical activity and to determine their influence on the physical condition of children aged 3-4 years attending pre-school institutions of various types.

Material: $\quad$ the research was carried out in pre-school educational institutions of various types in the city of Dnepr (Ukraine) (№ 282, combined type, № 192, sanatorium type, № 28, compensatory type, № 244 and № 404, general development). One hundred and eighty-five children took part in the research, 103 of them were 3 -year-olds and 82 - preschoolers of 4-year-old age. Control and experimental groups were formed in each age group in kindergartens of a certain type. The control group consisted of 91 children, the experimental group - 94. In the study we used measurements of anthropometry, pulsometry, spirometry, functional tests. The obtained results were processed by independent $t$-test to evaluate differences between groups.

Results: $\quad$ the functional conditions of the children's study of the experimental groups (boys and girls) have positive changes in the spirometry indices, respiration rates, pulsometry, Ruffier index with a significant difference with the control groups $(p<0,05)$. In addition, in the course of our research, the parameters of the motor activity of children 3-4 years were determined on the base of pacing, while carrying out various organizational forms of physical education. These indicators can be oriented towards the development of a rational motor regimen for younger preschool children.

Conclusions: the proposed regimes and forms of motor activity can be used in the organization of physical education of children in pre-school educational institutions of different types for the improvement of morphofunctional indices and physical activity.

Keywords: children, physical activity, physical education, health technologies, innovative approaches.
\end{abstract}

\section{Introduction}

The development of Ukraine (as an independent state) is accompanied by complex socio-economic problems that have led to a deterioration in the physical, mental and financial situation of most of the country's population. Particular concern is the fact of the decline in the health of preschool children. The data of scientific researches show that $80 \%$ of preschool children have diseases of the upper respiratory tract, $60 \%$ - have a violation of posture and $50 \%$ of children have neurological diseases $[1,2,3]$.

One of the leading factors affecting the health level and physical condition is motor activity. It is known that at the preschool age the biological need for movement is leading and has a mobilizing effect not only on the physical, but also on the intellectual, moral and emotional development of the child, his habits and behavior $[4,5,6]$.

Especially relevant is the realization of this need at preschool age, since the longest and most complex stage of early ontogeny is the period from 3 to 6-7 years. It is at this age that the mechanisms of personal growth begin to develop [7, 8, 9].

In recent years, studies have been conducted on the issues of increasing the efficiency of physical education in preschool institutions. The organizational, pedagogical and methodological basis for improving the system of physical education of preschool children is presented in the studies of many authors. Researchers Wilchkovsky E.S., Denisenko N.F. [10] revealed the peculiarities of the

(C) Moskalenko N.V., Poliakova A.V., Sidorchuk T.V., 2018 doi:10.15561/18189172.2018.0507 organization of the motor mode of children in pre-school educational institutions. Also, the authors presented pedagogical conditions for activating the motor mode of preschool children. These include: the development of interest in motor activity, the creation of a sports environment, the management of independent motor activity, the organization of active recreation for children and others.

Pangelova N.E. [2] developed the concept of the formation of a harmoniously developed personality of children aged 4-6. The concept included: the urgency of modernizing the modern system of pre-school physical education; purpose, tasks and principles of technology for the integrated development of the pre-schooler's personality in the process of physical education; organizational and methodological foundations for the implementation of the concept; staffing, the strategy of introducing the concept into the practice of physical education of pre-school educational institutions.

Krutsevich T.Yu. [11] defined the interaction of "childpedagogue-children's collective" as a leading principle of development of moral qualities of children's personality.

Costa H.J. and others [12] presented the impact of structured programs and physical education classes with pre-school children on physical fitness indicators.

At the same time, the issue of optimizing the motor state of children 3-4-years in pre-school educational institutions of various types was not the subject of special research, but determined the relevance of this study.

The aim of the research is to develop rational regimes 
of physical activity and to determine their influence on the physical condition of children aged 3-4 years attending pre-school institutions of various types.

\section{Material \& methods}

Participants. One hundred and eighty-five children took part in the research, 103 of them were 3-year-olds and 82 - preschoolers of 4-year-old age. Control and experimental groups were formed in each age group in kindergartens of a certain type. The control group consisted of 91 children, the experimental group - 94 .

The control group included 48 children of 3-4-yearold age from pre-school educational institutions (PEI) of general development and combined types and 43 children of 3-4-year-old age from PEI of sanatorium and compensatory types. The experimental group included 50 children of 3-4-year-old age from PEI of general development and combined types and 44 children of 3-4-year-old age from PEI of sanatorium and compensatory types.

Participation of children in the experiment is confirmed by the consent of their parents.

Procedure. The research was carried out in pre-school educational institutions of various types in the city of Dnepr (Ukraine) (PEI № 282, combined type, PEI № 192, sanatorium type, PEI № 28, compensatory type, PEI № 244 and № 404, general development). The experiment lasted 9 months.

The contents of the motor activity of pupils in PEI of general development and combined type was supplemented by author's methods, means of psychopreventive work, children's fitness and hardening measures. Innovative and health-improving technologies were used in all organizational forms of work on physical education. They are: story-playing physical culture (with elements of fairy-tale therapy [13], eurythmic gymnastics [14], children's fitness [15], techniques "Children's experimentation", "Little wizards", "Training in motion" [16], technologies for the comprehensive development of the child's personality [2]. Classes were held at least twice a week, swimming (in PEI № 404) - twice a week (after noon). Physical culture activities (morning exercises, walking games, gymnastics after a daytime sleep, etc.) included the elements of psycho-gymnastics [17], corrective gymnastics (logarithmic gymnastics, exercises for the development of fine motor skills $[18,19]$, health running, hardening activities at least three times a week. Active recreation included physical culture holidays (for children in the middle group every 3 months), health days (once a month), physical recreation (twice a month), walking in the forest or the adjoining park (for children in the middle group 2 -3 times a month). Independent motor activity for children was organized on a daily basis, under the guidance of the tutor, taking into account the level of motor activity of children.

For the pupils in PEI of sanatorium and compensatory type, physical education classes were held three times a week. Their content is supplemented by author's methods, such as: "The Theater of Physical Education" [20],
"Free Physical Education" [21], "Technology of Integral Development of Psychomotor Abilities of Children 2-5 years" [22]. Elements of psycho-prophylactic work, corrective gymnastics (sets of exercises using therapeutic balls SIT-45) and elements of children's fitness program "Sa-Fi-Dance" [23] were used too. The organization of physical and health activities, along with traditional ones (morning gymnastics, outdoor games and exercises on a walk, etc.) also provided for carrying out the daily recreational and gaming practice. The content of active recreation forms and independent motor activity provided for the use of both traditional and innovative means of preschool physical education.

In our studies we used measurements of anthropometry, pulsometry, spirometry, functional tests.

Statistical analysis. The obtained results were processed using mathematical statistics methods: descriptive statistics, independent t-test to evaluate differences between groups $(\mathrm{p} \leq 0,05)$.

\section{Results}

The increase in the level of the physical condition largely depends on the optimal motor mode in the preschool institution. Its content is a complex of organizational forms in physical education (PE lessons, fitness and recreation in the mode of the day, active recreation, independent motor activity of the child, etc.), which is used in the pedagogical process of preschool institution.

When developing a rational motor regime, it is important not only to ensure the biological need of children for motor activity. It is also necessary to provide a rational content of motor activity based on the optimal correlation of different organizational forms of studies, selected according to the age, individual characteristics of children, and the profile of the pre-school educational institution. These approaches were implemented in the following forms of organization of physical education work in conditions of the pre-school educational institution: PT lessons, sport and recreational activities in the mode of the day, active rest, independent motor activity of children in the mode of the day in PEI.

The construction of a rational motor regime required taking into account the specifics in the activity of a preschool educational institution.

For preschool institutions of general development we recommend both generally accepted forms of work (PT lessons, fitness activities in the mode of the day, etc.) and such types of motor activities as health-improving running, respiratory gymnastics, logarithmic gymnastics. This is because in kindergartens of general development a significant number of children have low and below average indicators of the functional state of the organism and insufficient development of speech. In PEI № 404, where there is a swimming pool, twice a week, swimming lessons were carried out in combination with hydro massage, gymnastics in the water, hardening activities.

Pre-school institutions of compensatory type are intended for children who need correction of physical and 
mental development (with lack of hearing, sight, speech, musculoskeletal system). An analysis of the morbidity of children in PEI № 28 (compensating type) made it possible to state that the overwhelming number of pupils have visual, musculoskeletal system impairments and others; individual functional indicators (heart rate, vital capacity of the lungs) do not correspond to the average age norms. The indices of physical preparedness and motor activity were also lower than the indices of preschool pupils in PEI of general development. All this led to a change in the ratio of the various organizational forms of physical exercise (reducing the number of PT lessons at the expense of health-gaming sessions, the use of varieties of corrective gymnastics, etc.).

The main contingent in preschool institutions of a sanatorium type are children who have early manifestations of tuberculosis infection, often suffer from colds or diseases of the gastrointestinal tract, endocrine and cardiovascular systems. Pupils in PEI №192 are characterized by a high incidence rate in comparison with other groups of children under study. Evaluation of the functional state of children in PEI of a sanatorium type indicates that the adaptive capacity of their body is lower than that of pupils at the general development level. In addition, such a component of the physical state as physical fitness corresponds to a level below the average, and the level of motor activity is low. Therefore, the process of physical education had mainly a healthadaptive orientation. Particular attention was paid to hardening procedures, respiratory gymnastics, and the use of health-saving technologies.

The rational combination of various forms of physical exercise is a whole complex of educational and recreational activities, ensuring optimal motor activity of children (Table 1).

Table 1. Forms of work and types of motor activity of children aged 3-4 years

№ Activities

Features of the organization

\section{PEI *}

№244,

404

1. Physical training

1.1 Physical training lessons

Swimming classes (if

1.2 there is a swimming pool)
5 times (2 - outdoors) per week in PEI of general development and combined type, 3 times (1outdoors) in PEI of sanatorium and compensatory type

Twice a week, in the afternoon, subgroups (8-10 children). Duration - 25-30 minutes.

2. Fitness and health activities in the mode of the day

Daily outdoors (in the warm season) or in the hall. Duration: 5-6 minutes. (second junior group); 6-8

$2.1 \quad$ Morning exercises min. (middle group).

Exercises to correct posture and prevent flat feet. Breathing exercises to improve the drainage function of the lungs and bronchi.

Every day during the morning walk in subgroups formed with regard to the motor activity level of

2.2 Moving games and exercise for a walk

2.3 Health running Individual work on

2.4 the development of movements

Gymnastics after a daytime sleep

Hardening procedures in combination with physical exercises Recreational and gaming practice children and their physical condition. Duration - 2025 minutes.

Twice a week, in subgroups of 5-7 children, during the morning walk. Duration - 3-5 min.

Daily during the evening walk. Duration - 10-12 minutes.

Daily after a daytime sleep. Duration - 5-8 minutes, 4-5 exercises.

Daily during active motor activity, after sleep and during other routine activities.

Daily after a daytime sleep. Duration - 25-30 minutes.

Daily after a daytime sleep (during the health-game practice). In addition, complexes of corrective exercises can be used in other forms of physical culture and health. It is carried out on doctor's recommendation. Duration - 10-12 minutes.
№282 №192 №28
$+$

$+$ 


\begin{tabular}{|c|c|c|c|c|c|c|}
\hline № & Activities & Features of the organization & $\begin{array}{l}\text { PEI * } \\
\text { №244, } \\
404\end{array}$ & №282 & №192 & №28 \\
\hline 2.9 & Breathing exercises & $\begin{array}{l}\text { Daily in the process of organized forms of physical } \\
\text { education, as well as music classes. Duration - 8-10 } \\
\text { minutes. }\end{array}$ & + & + & + & + \\
\hline 2.10 & $\begin{array}{l}\text { Logarithmic } \\
\text { gymnastics }\end{array}$ & $\begin{array}{l}\text { Twice a week in subgroups (under the guidance of a } \\
\text { speech therapist) }\end{array}$ & + & + & + & + \\
\hline \multicolumn{7}{|c|}{ 3. Leisure } \\
\hline 3.1 & $\begin{array}{l}\text { Walking in the } \\
\text { forest or the } \\
\text { adjoining park }\end{array}$ & $\begin{array}{l}\text { Two or three times a month during the game and } \\
\text { exercise time, organized by the tutor. Duration - } 60 \text { - } \\
80 \text { minutes. (for children of the middle group) }\end{array}$ & + & + & + & + \\
\hline 3.2 & Athletic leisure & $\begin{array}{l}\text { Once or twice a month outdoors with peers of one } \\
\text { or two groups. Duration - } 20-30 \text { minutes. }\end{array}$ & + & + & + & + \\
\hline 3.3 & $\begin{array}{l}\text { Physical culture } \\
\text { holidays }\end{array}$ & $\begin{array}{l}\text { Twice or three times a year with children of other } \\
\text { PEI age groups (starting with the middle group). } \\
\text { Duration - } 60-80 \text { minutes. }\end{array}$ & + & + & + & + \\
\hline 3.4 & Health day & $\begin{array}{l}\text { Once a month. During the day active motor } \\
\text { activity of children in the open air. The content is } \\
\text { determined by the tutor. }\end{array}$ & + & + & + & + \\
\hline 3.5 & $\begin{array}{l}\text { Health Week } \\
\text { (vacation) }\end{array}$ & $\begin{array}{l}\text { Twice or three times a year (last week of the } \\
\text { quarter) }\end{array}$ & + & + & + & + \\
\hline \multicolumn{7}{|c|}{ 4. Self-study } \\
\hline 4.1 & $\begin{array}{l}\text { Independent motor } \\
\text { activity }\end{array}$ & $\begin{array}{l}\text { Daily under the guidance of a tutor indoors and } \\
\text { outdoors. Duration depends on the individual } \\
\text { characteristics of the children }\end{array}$ & + & + & + & + \\
\hline
\end{tabular}

Notes: * PEI № 244, 404 - general development; PEI №282 - combined type; PEI №192 - sanatorium type; PEI №28 compensatory type.

Table 2. Indicative figures of motor activity for children aged 3-4 years

\begin{tabular}{|c|c|c|c|}
\hline & Indices of motor activity & & \\
\hline Activities & $\begin{array}{l}\text { The volume of } \\
\text { movements (the number } \\
\text { of locomotions) }\end{array}$ & $\begin{array}{l}\text { Duration } \\
\text { (min.) }\end{array}$ & $\begin{array}{l}\text { Intensity of } \\
\text { movements } \\
\text { (min.) }\end{array}$ \\
\hline Morning exercises & $580-750$ & $5-8$ & $48-52$ \\
\hline Physical activity & $1700-2900$ & $20-30$ & $42-58$ \\
\hline $\begin{array}{l}\text { Outdoor games and exercises for a morning } \\
\text { walk }\end{array}$ & $1600-2500$ & $20-25$ & $40-55$ \\
\hline $\begin{array}{l}\text { Individual work with children to develop } \\
\text { movements for an evening walk }\end{array}$ & $900-1400$ & $10-12$ & $40-50$ \\
\hline Gymnastics after a daytime sleep & $500-700$ & $5-8$ & $42-50$ \\
\hline Recreational game practice & $1700-2500$ & $25-30$ & $45-58$ \\
\hline $\begin{array}{l}\text { Independent motor activity of children for a } \\
\text { morning walk }\end{array}$ & $2000-2500$ & $45-50$ & $40-45$ \\
\hline $\begin{array}{l}\text { Independent movements indoors and other } \\
\text { movements in the mode of the day }\end{array}$ & $1100-1400$ & $30-35$ & $38-42$ \\
\hline $\begin{array}{l}\text { Independent motor activity of children for an } \\
\text { evening walk }\end{array}$ & $1200-1400$ & $40-45$ & $30-32$ \\
\hline $\begin{array}{l}\text { Independent children's games indoors and } \\
\text { other movements in the afternoon }\end{array}$ & $1100-1200$ & $30-35$ & $28-32$ \\
\hline Total per day & $13100-17800$ & $235-280$ & $44-53$ \\
\hline
\end{tabular}


Table 3. Parameters of the morphofunctional state of girls of 3 and 4 years of control and experimental groups

\begin{tabular}{|c|c|c|c|c|c|c|c|}
\hline \multirow[b]{3}{*}{ Indicators } & & \multicolumn{2}{|c|}{ Before the experiment } & \multicolumn{4}{|c|}{ After the experiment } \\
\hline & & \multirow{2}{*}{$\begin{array}{l}\text { PEI of general } \\
\text { development } \\
\text { and combined } \\
\text { type ( } 3 \text { years } \\
n=30,4 \text { years } \\
n=21 \text { ) }\end{array}$} & \multirow{2}{*}{$\begin{array}{l}\text { PEI of } \\
\text { sanatorium } \\
\text { and } \\
\text { compensatory } \\
\text { type ( } 3 \text { years } \\
n=24 \text {, } 4 \text { years } \\
n=20 \text { ) }\end{array}$} & \multicolumn{2}{|c|}{$\begin{array}{l}\text { PEI of general development } \\
\text { and combined type }\end{array}$} & \multicolumn{2}{|c|}{$\begin{array}{l}\text { PEI of sanatorium and } \\
\text { compensatory type }\end{array}$} \\
\hline & & & & $\begin{array}{l}\text { CG ( } 3 \text { years } \\
n=15,4 \text { years } \\
n=10)\end{array}$ & $\begin{array}{l}\text { EG ( } 3 \text { years } \\
n=15,4 \text { years } \\
n=11)\end{array}$ & $\begin{array}{l}\text { CG (3 years } \\
n=12,4 \\
\text { years } n=10)\end{array}$ & $\begin{array}{l}\text { EG ( } 3 \text { years } \\
n=12,4 \text { years } \\
n=10)\end{array}$ \\
\hline & & $\bar{x} \pm \sigma$ & $\bar{x} \pm \sigma$ & $\bar{x} \pm \sigma$ & $\bar{x} \pm \sigma$ & $\bar{x} \pm \sigma$ & $\bar{x} \pm \sigma$ \\
\hline \multirow{2}{*}{$\begin{array}{l}\text { Body length, } \\
\mathrm{cm}\end{array}$} & $\begin{array}{l}3 \\
\text { years }\end{array}$ & $100,00 \pm 0,75$ & $97,00 \pm 0,94$ & $102,80 \pm 0,69$ & $102,60 \pm 0,71^{*}$ & $99,50 \pm 0,59$ & $99,70 \pm 0,61^{*}$ \\
\hline & $\begin{array}{l}4 \\
\text { years }\end{array}$ & $107,0 \pm 1,56$ & $108,5 \pm 1,47$ & $109,8 \pm 1,51$ & $110,2 \pm 1,51^{*}$ & $110,1 \pm 1,31$ & $111,0 \pm 1,61^{*}$ \\
\hline \multirow{2}{*}{$\begin{array}{l}\text { Body weight, } \\
\text { kg }\end{array}$} & $\begin{array}{l}3 \\
\text { years }\end{array}$ & $14,70 \pm 0,32$ & $13,50 \pm 0,32$ & $16,20 \pm 0,38$ & $15,90 \pm 0,41^{*}$ & $14,60 \pm 0,39$ & $14,50 \pm 0,42^{*}$ \\
\hline & $\begin{array}{l}4 \\
\text { years }\end{array}$ & $17,8 \pm 0,65$ & $18,8 \pm 0,71$ & $19,2 \pm 0,68$ & $19,5 \pm 0,71^{*}$ & $20,2 \pm 0,81$ & $20,3 \pm 0,61 *$ \\
\hline \multirow{2}{*}{$\begin{array}{l}\text { Mass-growth } \\
\text { index, } \mathrm{g} \bullet \\
\mathrm{cm}^{-1}\end{array}$} & $\begin{array}{l}3 \\
\text { years }\end{array}$ & $146,70 \pm 2,98$ & $147,60 \pm 2,55$ & $164,20 \pm 2,67$ & $167,30 \pm 2,53^{*}$ & $163,40 \pm 2,38$ & $165,70 \pm 2,71^{*}$ \\
\hline & $\begin{array}{l}4 \\
\text { years }\end{array}$ & $166,8 \pm 4,22$ & $172,5 \pm 5,43$ & $178,7 \pm 5,71$ & $181,2 \pm 6,12 *$ & $183,2 \pm 4,71$ & $185,4 \pm 5,67^{*}$ \\
\hline \multirow{2}{*}{$\begin{array}{l}\text { Heart rate, } \\
\text { stroke } \bullet \\
\text { min-1 }\end{array}$} & $\begin{array}{l}3 \\
\text { years }\end{array}$ & $104,00 \pm 0,41$ & $109,00 \pm 0,45$ & $103,00 \pm 0,61$ & $99,00 \pm 0,51^{*}$ & $108,00 \pm 0,51$ & $104,00 \pm 0,61^{*}$ \\
\hline & $\begin{array}{l}4 \\
\text { years }\end{array}$ & $95 \pm 0,51$ & $102 \pm 0,81$ & $94 \pm 0,73$ & $91 \pm 0,51^{*}$ & $102 \pm 0,67$ & $96 \pm 0,74^{*}$ \\
\hline \multirow{2}{*}{$\begin{array}{l}\text { Vital } \\
\text { capacity of } \\
\text { the lungs, ml }\end{array}$} & $\begin{array}{l}3 \\
\text { years }\end{array}$ & $910,00 \pm 11,40$ & $875,00 \pm 10,50$ & $950,00 \pm 11,30$ & $1100,00 \pm 10,90 *$ & $920,00 \pm 10,70$ & $980,00 \pm 11,20^{*}$ \\
\hline & $\begin{array}{l}4 \\
\text { years }\end{array}$ & $1020 \pm 916,6$ & $890 \pm 17,6$ & $1050 \pm 7,91$ & $1290 \pm 5,83^{*}$ & $920 \pm 9,71$ & $1090 \pm 8,93 *$ \\
\hline \multirow{2}{*}{$\begin{array}{l}\text { Respiration } \\
\text { rates, cycle • } \\
\min ^{-1}\end{array}$} & $\begin{array}{l}3 \\
\text { years }\end{array}$ & $27,00 \pm 0,53$ & $31,50 \pm 0,61$ & $27,00 \pm 0,51$ & $23 \pm 0,27^{*}$ & $30,00 \pm 0,32$ & $25,00 \pm 0,21^{*}$ \\
\hline & $\begin{array}{l}4 \\
\text { years }\end{array}$ & $25 \pm 0,61$ & $29,5 \pm 0,55$ & $25 \pm 0,31$ & $21 \pm 0,11 *$ & $28 \pm 0,21$ & $24 \pm 0,12^{*}$ \\
\hline \multirow{2}{*}{$\begin{array}{l}\text { The Ruffier } \\
\text { Index, } \\
\text { points }\end{array}$} & $\begin{array}{l}3 \\
\text { years }\end{array}$ & $10,80 \pm 0,67$ & $12,90 \pm 0,74$ & $9,20 \pm 0,41$ & $6,9 \pm 0,31^{*}$ & $11,80 \pm 0,31$ & $9,70 \pm 0,23^{*}$ \\
\hline & $\begin{array}{l}4 \\
\text { years }\end{array}$ & $8,5 \pm 0,75$ & $12,3 \pm 0,80$ & $8,2 \pm 0,53$ & $6,9 \pm 0,23 *$ & $12,0 \pm 0,61$ & $9,3 \pm 0,47^{*}$ \\
\hline
\end{tabular}

Notes: CG - control group, EG - experimental group, * - significant differences at $p<0,05$.

We proposed to include elements of recreational and innovative pedagogical technologies of physical education in all organizational forms of work on physical education, taking into account the specifics of a preschool educational institution of a certain type. They contribute to the optimization of the motor regime in PEI in conjunction with the program material for the education and upbringing of children of younger preschool age.

In addition, in the course of our research, the parameters of the motor activity of children 3-4 years were determined on the base of pacing, while carrying out various organizational forms of physical education used in working with children 3-4 years (Table 2). These indicators can be oriented towards the development of a rational motor regimen for younger preschool children attending children's institutions of various types.

Comparison of the data obtained during the educational pedagogical experiment indicates that in the experimental groups children 3-4 years (boys and girls) attending PEI of different types had significantly higher results in terms of physical condition than children in control groups. This confirms the effectiveness of forming a rational motor regime in pre-school educational institutions of different types.

Thus, the results of a study of the functional capabilities of the children's study groups indicate 
that in the experimental groups positive changes in the spirometry indices, respiration rates, pulsometry, Ruffier samples with a significant difference with the control groups $(\mathrm{p}<0,05)$.

The indicators of the physical development of children 3-4 years also significantly changed, which can be explained by the natural growth of the body (Tables 3,4 ).

\section{Discussion}

Summarizing the results of the study of the functional state, it should be noted that their rates, both at girls and at boys who have certain abnormalities in their health and attend dentistry of sanatorium and compensatory types, are lagging behind the average values for children 3-4 years.

Scientists came to the conclusion about the dependence of mental and physical development of the child on the level of motor activity. They determined that the driving factor in increasing the physical condition of children of preschool age is motor activity, which is within the optimum values $[1,2,24]$. Our studies confirmed the data of scientists $[2,8,10,25]$ on the dependence of the morphofunctional state of children on the level of their motor activity. Consequently, rational construction of the motor regime of the child is one of the most important tasks of the system of preschool physical education.

The organization of a rational mode of physical activity of children of preschool age includes the use of various forms of physical education, means and methods of their application, which correspond to the age characteristics of children. The recommended weekly volume of motor activity of children 3-4 years old is $15-20$ hours [10, 26]. However, these recommendations are generalized and do not take into account the specifics of a kindergarten of a certain type.

Thus (taking into account the peculiarities of the morphofunctional state of children 3-4 years old, pupils of different types PEI) we have introduced various traditional and non-traditional means of motor activity into all organizational forms of work for physical education. We also proposed the orientation parameters of the motor activity of children 3-4 years old during the day.

The results of the study have proven the effectiveness of the proposed motor regimens for children who attend PEI of different types. There is a statistically significant improvement in the morphofunctional indices of children in experimental groups as compared to control groups.

\section{Conclusions}

Thus, the data confirm the advisability of using the proposed approaches to improve the motor conditions of children in pre-school educational institutions of various types.

\section{Conflict of interests}

The authors declare that there is no conflict of interest.

\section{References}

1. Krutsevich T, Pangelova N. Content and organization of physical education in the context of formation of integrated harmoniously developed child. Life and movement. 2013;1(3):3-7.

2. Pangelova NY. Theoretical and methodical principles of forming a harmoniously developed personality of a child of preschool age in the process of physical education. Cand. Diss., Kiev; 2014. (in Ukrainian)

3. Poliakova AV. Organizational-methodical principles of the motor regime of children aged 3-4 years in preschool institutions of different types. Cand. Diss., Dnipropetrovsk; 2015. (in Ukrainian)

4. Benčuriková L', Putala M. The influence of motor activity on the swimming ability of preschool aged children. Journal of Physical Education and Sport, 2017;17(3):1043 - 1047. doi:10.7752/jpes.2017.03160

5. Marouli A, Papavasileiou G, Dania A, Venetsanou F. Effect of a psychomotor program on the motor proficiency and self-perceptions of preschool children. Journal of Physical Education and Sport, 2016;16 (4):1365 - 1371. doi:10.7752/ jpes.2016.04218

6. Leng Goh T, Fu Y, Brusseau T, Hannon J. On-task behavior of elementary students during movement integration. Journal of Physical Education and Sport, 2018;18(1):103 - 106. doi:10.7752/jpes.2018.01013

7. Vygotskij LS. Child developmental psychology. Moscow: EKSMO; 2003. (in Russian)

8. Goldfield GS, Harvey A, Grattan K, Adamo K. B. Physical Activity Promotion in the Preschool Years: A Critical Period to Intervene. International Journal of Environmental Research and Public Health, 2012;9 (4): 1326-1342. doi. org/10.3390/ijerph9041326

9. Pica R. Why Preschoolers Need Physical Education. Young Children. 2011;66 (2):56-57.

10.Vil'chkovs'kij ES, Denisenko NF. Organization of motor regime for children in pre-school educational institutions. Ternopil: Traveler; 2008. (in Ukrainian)

11.Krutsevich T. Development of the moral component of the personality of senior preschool children in the process of organized motor activity. Sportivnij visnik Pridniprov'ia, 2015;2:93 - 97. (in Ukrainian)

12.Costa HJ, Abelairas-Gomez C, Arufe-Giráldez V, PazosCouto JM, Barcala-Furelos R. Influence of a physical education plan on psychomotor development profiles of preschool children. Journal of Human Sport \& Exercise, 2015;10 (1):126 - 140. doi:10.14198/jhse.2015.101.11

13.Iefimenko MM. Sporting fairy tales. Kharkiv: Vesta, Ranok; 2005. (in Ukrainian)

14.Skvorchuk E. Eurythmic gymnastics. Doshkol'noe vospitanie, 2008;5:16-19. (in Russian)

15.Sajkina EG. Fitness in the system of preschool and school education. Dokt. Diss., Sankt Petersburg; 2009. (in Russian)

16. Shebeko V. Education of the child as a subject of physical culture and recreation. Doshkol'noe vospitanie, 2011;4:2833. (in Russian)

17.Chistiakova MI. Psychogymism. Moscow: Education; 2010. (in Russian)

18.Savel'eva NIu. Organization of health work in pre-school educational institutions. Rostov on Don: Phoenix; 2009. (in Russian)

19.Ushakova OS, Strunina EM. Methods of speech development for preschool children. Moscow: HOUSEHOLD; 2011. (in Russian) 
20.Iefimenko MM. Theater of physical education and rehabilitation of preschoolers. Kiev: ISDO; 1995. (in Ukrainian)

21.Glazyrina LD, Ovsiankin VA. Methods of physical education of children of preschool age. Moscow: HOUSEHOLD; 1999. (in Russian)

22.Lakhno OG. Innovative technologies of the development of psychomotor abilities in the physical education of children 2nd - 5th years of life. Cand. Diss. Kiev; 2013. (in Ukrainian)

23.Pangelova NIe, Moskalenko OV. Health-developing program "Sa-Phi-Danse" as a means of correction of the physical condition of children of the senior preschool age. Sportivnij visnik Pridniprov'ia, 2010;2:21-24. (in Ukrainian)
24.Axeti G, Gissis I, Vrabas I, Grouios G, Komsis G, Komsis S. Assessment of kinematic characteristics of preschoolers' gait during the implementation of an intervention training program. Journal of Human Sport and Exercise, 2017;12(4):1298-1309. doi:10.14198/jhse.2017.124.16

25.Chatoupis C. Young children's divergent movement ability: a study revisited. Early Child Development and Care, 2012;183 (1):92-108. doi:10.1080/03004430.2012.655728

26.Stork S, Sanders SW. Physical education in early childhood. Elementary School Journal, 2008;108(3):197-206.

\section{Information about the authors:}

Moskalenko N.V.; Vice-rector for Scientific Activities; http://orcid.org/0000-0001-9162-5206; moskalenkonatali2016@gmail.com; Pridneprovsk State Academy of Physical Culture and Sports; Naberezhna Pobedy str., 10, Dnieper, 49094, Ukraine.

Poliakova A.V.; http://orcid.org/0000-0002-4328-6083; polyakova.tonya@bk.ru; Department of Sports Games, Pridneprovsk State Academy of Physical Culture and Sports; Naberezhna Pobedy str., 10, Dnieper, 49094, Ukraine.

Sidorchuk T.V.; (Corresponding author); http://orcid.org/0000-0001-7129-1616; sydorchuk1704@gmail.com; Department of Theory and Methods of Physical Education, Pridneprovsk State Academy of Physical Culture and Sports; Naberezhna Pobedy str., 10, Dnieper, 49094, Ukraine.

Cite this article as: Moskalenko NV, Poliakova AV, Sidorchuk T.V. Construction of rational regimes in motor activity of children aged 3-4 years in pre-school educational institutions of various types. Pedagogics, psychology, medical-biological problems of physical training and sports, 2018;22(5):265-271. doi:10.15561/18189172.2018.0507

The electronic version of this article is the complete one and can be found online at: http://www.sportpedagogy.org.ua/index.php/PPS/issue/archive

This is an Open Access article distributed under the terms of the Creative Commons Attribution License, which permits unrestricted use, distribution, and reproduction in any medium, provided the original work is properly cited (http://creativecommons.org/licenses/by/4.0/deed.en).

Received: 18.08.2018

Accepted: 10.09.2018; Published: 30.09.2018 